Themina Kader The Pennsylvania State University Park PA 16802

\title{
Material Culture Studies and Art Education: Examining the Cultural Artifacts of the Bohra
}

The study of artifacts has its antecedents in archaeology and art history. To explore and understand these two epistemes is to acknowledge the variety of human experiences and behaviors associated with them. Dissanayake (1990) in her book What Is Art For? cogently explains the inseparable connection between art and behavior. Her approach is ethological or "bioevolutionary." She explains, "I will be concerned with the evolution and development of behavior ... that is as characteristic of humankind as toolmaking, symbolization, language, and the development of culture" (p. 6). She elaborates on the concept of behavior of art as something that is not necessarily compartmentalized into artistic activities such as painting, dancing, pottery or sculpture. Rather her thesis states that all these physical acts and many more are "art as a general behavior with many varied manifestations" (p. 8). She contends that this thought process allows for the inclusion of all the "arts" from all societies. From this premise, I view art to be a way of life in which there is room for virtually all human endeavors. This, of necessity, nurtures an inclusiveness that embraces all cultural artifacts.

What is art? This question has engaged artists in a discursive discourse since Plato wrote his treatise on What is Art? (Sesonske, 1965). Is a digitally constructed photograph on our television screen considered art? Would a winter landscape painted on a canvas be called art? What about the royal ivory mask of the Benin people (Fagg \& Plass, 1964, p. 66)? Can any of these "artworks" be independent of the person who made them? What were the processual decisions made and considerations given in their manufacture? How did they affect the lives of the people who made these artworks and the lives of those around them? According to Lavin (1983), "anything man-made is a work of art, even the lowliest and most purely functional 
object” (p. 98). Implicit in this statement is the assumption that all artifacts are works of art. However, culturally and historically, because artifacts comprise all manufactured and hand-made objects in Western societies, we have become conditioned to view them outside the realm of art. This has created pedagogic binaries between art and artifacts that are inconsistent with postmodern pluralistic trends prevalent in the United States (Congdon, 1985; Pocius, 1997).

A clear dichotomy, created by utilitarian values, existed and still exists, between objects and art (Hooper-Greenhill, 1992; Kingery, 1993; Newton, 1994; Weil, 1998). The former are generally associated with people and their daily lives. People use artifacts for social, religious, and cultural purposes and replace them when normal wear and tear has taken toll of their serviceability (Deetz, 1980; Gordon, 1993; Pearce, 1994). Judged by the number of museums that hold artworks from the past, art is unique and made for posterity (Alexander, 1979; Wallach, 1998). Its main function is to engage our visual sensibilities. Traditional aestheticians believe that an artwork evokes emotional responses in the viewer, and overlook the power of artifacts to do the same. The cognitive and affective domains that enable one to experience fully a work of art are equally at play when one interacts with an artifact. In fact, artifacts inform all the five senses and promote an appreciation of non-Western cultures (Hudson, 1991).

Art and artifacts are a reflection of a culture, past or present. In the context of $20^{\text {th }}$ century art, consider Duchamp's urinal exhibited as The Fountain by R. Mutt, in 1917. Although the jurors of the First New York Society of Independent Artists rejected the mundane urinal as art, Duchamp challenged the idea that art objects must be unique to be accepted as art and, resigned from the jury to which he was appointed, in protest. For Duchamp the ideas behind his artmaking transformed the mundane into a sacrosanct artwork. This raises questions of validity. Does an object have to be renamed to be accepted as art? Why cannot a chair be a chair and still be considered art? The extremely Eurocentric perspective, that explores such 
questions somewhat superficially, has had far-reaching adverse repercussions in the context of non-European culture and its presentation and representation (Arnoldi, Geary \& Hardin, 1996). It has created a separation of art and artifacts into two distinct camps that are justified by sociopolitical premises. Researchers such as McFee and Degge (1977), and Congdon (1985), have theorized that to do so has created an educational and cultural hierarchy that is ill advised in the United States at the start of a new millennium.

I posit the view that artifacts comprise all manufactured and hand-made objects. The field of material culture studies requires an objective reading of the artifact. Subjectivity, on the other hand, is the hallmark of artmaking and art. Prown (1991) says, "It would be absurd to exclude art from material culture" (p. 154). Art and artifacts are inextricably linked to each other, such that both terms are open to varied interpretations. However, sometimes artists choose to interpret and represent a given situation in a manner that conflicts with social norms, so that art is then considered not to provide an accurate interpretation of culture. Prown (1991) states that, "if art is different from other artifacts, then art poses problems for the analyst of material culture" (p. 144). He maintains that words and numbers, rather than artifacts, are the most accurate sources of information. What artifacts do, however, is reveal metaphorically the beliefs and values of the people that make and use them. According to Fernandez (1971), metaphors are essential elements in decoding the inherent beliefs and values embedded within a specific artifact. He defines a metaphor "as a sign, a combination of image and idea located between perception and conception, between a signal and a symbol. A signal is a perception that orients some kind of interaction" (p. 150). There are two types of metaphors - structural metaphors and textual metaphors. The former refers to the physicality of the experience as reflected by the object, and the latter points to the feelings generated by that experience. So, one describes the artifact first, and then makes deductions based on the "physical and intellectual 
interaction with the artifact" (p. 148). Finally the object as the metaphor for the experiences "unlocks the cultural beliefs" (p. 149). Thus, if artifactual metaphors denote cultural beliefs, how then can we apply the same principle to works of art that are a result of conscious intentionally created beliefs? Like texts, works of art are fiction, but they have within them an aesthetic quality and a metaphor. Artifacts as an expression of beliefs are quite different from material (art) that is expressive. Much of the work of feminist artists Betye Saar, Judy Chicago, and Faith Ringgold display images derived from material culture that is related to each individual artist's experiences. The study of art, "offers an entry to culture and a means for comparison" (Glassie 1997, p. 2). Glassie's statement is offered in the context surrounding the potters of Bangladesh. They engage in making artworks that range from utilitarian to decorative. The potter relishes the experience of designing and building a pot. In the series of procedures and actions that start when clay is dug from the earth and culminate into kalshi-a globular water jar - the Bangladeshi potters fulfill a creative impulse. It is no longer just pottery or other ceramic statuary per se; it is an all-embracing life-long experience and a direct reflection of their culture.

People throughout the world have many reasons for making things: to perpetuate skills learned and passed down from parent to offspring, to propitiate ancestors, or to satisfy mementoseeking tourists. In each case they are making art, and in the process sharing knowledge, making meaning of the world and bringing meaning to their life. From the perspective of the makers of these artifacts whether it is considered to be "high art" or not is irrelevant. The politics of postmodernism has created a paradigm shift from a formalist/elitist viewpoint to an "understanding of objects, their use, or their appreciation in culture-specific terms" (Arnoldi \& Hardin, 1996, p. 4), so that the polemics of ethnography over aesthetics is reified. In a country like the United States, the advent of artifacts in the life of its people is so pervasive that it seems 
undesirable to separate art from artifacts. To do so is to make the latter into appendages rather than to fashion them into the primary limbs of a body. It is in this context that I now examine the relationship of artifacts and art education.

\section{Material Culture and Art Education}

"Art educators have been slow to draw on inquiry methods and information that are plentiful within the research field of material culture studies" (Bolin, 1993, p. 143). Part of the reason for this has been the perceived binary distinction between high and low art. The pedagogy of material culture has often been misunderstood and misrepresented in schools in the United States. This is because there is still a great deal of uncertainty about what constitutes material culture and whose culture should become the focus of pedagogy (Congdon, 1985). Material culture is quite commonly associated with "folk." The connotation of "folk," thus, implies a hierarchy that denigrates the work of a large portion of a particular region's population. Before the end of the $19^{\text {th }}$ century, intense interest in the collection, preservation and reproduction of folk artifacts spawned literature on folk artifacts, folk museums, and even a society for folklore. All this activity, however, did not accomplish the one thing that would have legitimized the study of folk art. It lacked a theoretical foundation.

Congdon (1985) believes that artifacts or the study of material culture (under the rubric of folk art) must have "tradition" and must "display folk tendencies" (p. 66). These two characteristics are in themselves misleading for art teachers. How do art teachers differentiate the tradition of an $18^{\text {th }}$ century pewter teapot from a Wal-mart plastic mug? Tradition suggests age and is grounded in time and space. Will art teachers accept the "tradition" of a plastic mug and consider it worthy of serious analysis? Congdon's second characteristic is equally contentious. An object is said to display folk tendencies if it has the following five prerequisites:

(a) It is intended to be used in everyday life among members of a small, close group. (b) It 
functions as a remembrance of the past or as a demonstration of respect for elders. (c) It demonstrates a re-creative process. (d) It is created by persons who do not call themselves artists as readily as artists from other areas of art. (e) The artist and/or group members use a different language structure from the art school or university trained artist to talk about the $\operatorname{artwork}($ p. 66).

Examine the plastic mug. Folks use it, but is it "folk" and is it "art?" Is the pewter teapot more "folk" and more "art" than the Wal-Mart mug? The logic of my argument emanating from Congdon's lenses is that folk art has too many imponderables and ambiguities. These are centered around conflicts of definition, location, language and aesthetics, the praxis of art education versus "folk" education, the lack of teachers who are knowledgeable of folk art, and the ill preparedness of institutions of higher education to address this subject. The field of material culture studies may create confusion in the mind of art teachers because of the uncertainty over whether an artifact being studied should be considered antiquated or modern. Antique objects or "marginal objects" as Gottdiener (1995) suggests, signify "historicity and otherness" (p. 45). This dichotomy leads well into Congdon's analysis of folk art as being "culture bound" and "culturally changing" (p. 72). It also exacerbates the dilemma created by the shifting emphasis from the home - the milieu within which artifacts were traditionally situated - to the school.

Thus, the overarching questions I address are ethnographic in nature. How can cultural artifacts that are considered "craft" narrow the gap between European and non-European cultures based on sociological, political, and ideological constructs? As Silvers states, (1999) "abandoning the distinction between art and craft brings us closer to European antiquity, which did not draw this distinction" (p. 97). Hence, the focus of my inquiry is on how the study of artifacts can help eliminate distinctions that have been drawn and are still prevalent between art 
and artifacts (Bolin, 1995; Lock, 1998). Using the pedagogy of material culture studies, I

examine (1) the problematic of linkage between material culture studies and art, mediated by the artifacts of a specific culture - the Bohra. As defined by Gordon, (1993), backward linkage alludes to the origins of artifacts and forward linkage to their uses. Functionality of artifacts resides in a cultural realm in which human endeavor and creativity are interwoven. In contrast to this, art and art making, very much products of human creative impulse, manifest themselves in ways that are only dissimilar in their intent from those of artifact making. Function implies service and as Gablick (1995) has noted, "in our culture, the notion of art being in service to anything [italics in the original] is anathema. Service has been totally deleted from our view of art ... I would like to change that" (p. 196). Thus, the second purpose of this study is to ask and answer: (2) How do functions of dress, containers, and furniture represent the cultural identity of a people who are dispersed throughout the world as the Bohra are? Artifacts can be used to understand how cultures function. They can be seen, touched, felt, and tasted, and can serve as catalysts for a dialogue, in which there is room for celebration and understanding of those objects that may or may not perform similar functions in other cultures (McFee \& Degge, 1977).

The study of material culture has pedagogical and phenomenological underpinnings for art education. The case study I have selected demonstrates the efficacy of artifacts as vehicles of learning for art educators who wish to venture into a newer approach to teaching art.

\section{Recontextualizing Artworks}

Prown, an art historian, uses an $18^{\text {th }}$ century pewter teapot to understand a painting titled Roman Charity: Cimon and Pero by Dirck van Baburen. He uses the theories of semiotics to make connections between a metallic vessel and a human breast as receptacles that supply nourishment. He maintains that the pewter teapot and the breast in and of themselves are nothing more than objects, but each becomes a symbol of beliefs and values when examined 
within the context of a culture. In deconstructing the teapot, the breast is recontextualized and the painting showing a man sucking at a younger woman's breast is not something gruesome and depraved, but an act of charity. Prown suggests three steps essential to the process of object analysis. The first is the description, followed by "deductions based on the physical and intellectual interaction with the object" (Prown, cited in Pocius, 1991, p. 149), and the final step is the emotional response. This is when the object as a metaphor - the tool of semiotics - brings to the fore, through recollections and probing, the experiences and emotions related to the object and signified by it. The teapot—a metaphor for giving and receiving, sociability and hospitality, love and the gratification of thirst—-becomes an indicator of deeply held beliefs and values. The physical shape of the teapot looked from above resembles a breast and the young woman-a daughter who offers her breast to an elderly man — her imprisoned and chained father-is the ultimate symbol of charity. Whereas, intentional expression of belief is inherent in art, the unconscious expression embedded in artifacts must be prized open and discovered.

This brief analysis was meant to elucidate the manner in which artifacts become works of art themselves and help analyze other art. Consider, for example, the seventeenth century Dutch genre paintings. Vermeer's The Letter was painted in 1666. According to Janson (1997), "the cool, clear day light that filters in from the left is the only active element, working its miracles upon all objects in its path" (pp. 593). Janson continues in this vein about "a mosaic of colored surfaces," and "rectangles predominate," "there are no "holes," no undefined empty spaces" (p. 593). Thus, is DBAE advocating the study of material culture? I share Janson's enthusiasm for the artistry of Vermeer's brush that enabled him to depict light so realistically. But, I wonder at the lost opportunity to talk about the artifacts and their metaphoric messages. The clothes of the two women, who "exist in a timeless 'still life' world" speak volumes. What is the power relationship of the two women as signified by the clothes they wear? Why is the standing 
woman's hair completely covered? What does the richness of the drapes indicate? What about the clothesbasket and the broom in an opulent room? What do the paintings on the wall symbolize? Does the abundance of brown in the painting mean anything other than that Vermeer may have had a predilection for this hue? These and many more questions could be asked about this painting.

An even more famous painting by Jan van Eyck, is the resplendent Wedding Portrait (1434). Countless numbers of art teachers, taking their cue from art history books, have deconstructed this painting. How many have talked about the shoes that have been discarded? Yes, the couple is standing on "holy ground." But who made the shoes? Is the design Dutch in origin? We are told about the reflection of two additional people in the mirror. But, where was the mirror made? And the ornate candelabra? What about Arnolfini's hat? The structural metaphors that give credence to the textual metaphors in these two examples are more than just physical descriptors (Fernandez, 1971). They locate the paintings within an environment that relates to the social and religious mores of their time. Are the artifacts just adjuncts to the paintings? If their relevance in the painting were not essential why would the artist include them? In material culture studies, everything grand and small has significance (Berger, 1992).

The study of material culture is a synthesis of relationships. These relationships draw us back and forth from the past to the present and then into the future. I have discussed, briefly, the efficacy of including artifacts in art education. I conclude this paper by sharing with you the memory of a celebration in a Bohra home that introduces you to their artifacts.

\section{A Celebration: Misaaq Mubaarak}

It is a blustery cold evening. 50 Manor Farmhouse is all spruced up, and the aroma of seasoned bakhoor (incense) blends well with the mouth-watering flavors of akni and khurdi (rice and lamb cooked in milk and mint). The floor of the spare bedroom is covered with a 
jazam (a block-printed cotton carpet), and two safra (square place mats), each with a kundli on it, are spread on the jazam. A kundli is a 36 long and 12 inches wide brass sheet folded over and welded to form a circular "table" of 18 inches in diameter. Everything is ready for the guests who are expected to arrive at about 6. 15 p.m. This is a Thursday in late-July 1993, and I am in London at my brother's house. We are celebrating his daughter's misaaq-a coming-of-age at puberty—ceremony. The thaal (stainless steel round tray three feet in diameter), with a namak dani (a small shallow bowl for salt) on it, is carried in and placed on the kundli as soon as the guests take their places round the safra. Men sit separately from women during jaman (communal eating), but because all the visitors are teenagers — friends of my niece—-the rule is bent. Besides, numerically men are in the minority this evening. Each thaal has eight people sitting around it. When the guests arrive, the girls are a little self-conscious dressed in their pretty ridah (the outer garment representing a veil). The ridah are all different colors. The men's outfit is all white - a kurta, eezaar, and a topi (a loose calf-length, long sleeved shirt, long trousers and a cap). My brother calls out Bismillahi-rahmani-raheem. That is the signal to begin the meal. But, first, each person must take a pinch of salt from the namak dani, and then partake of the food. 


\section{REFERENCES}

Alexander, E. P. (1979). Museums in motion: An introduction to the history and functions of museums. Nashville, TN: American Association for State and Local History.

Arnoldi, M. J., Geary, C. M., \& Hardin, K. L. (Eds.). (1996). African material culture. Bloomington, IN: Indiana University Press.

Bolin, P. E. (1992-93). Artifacts, spaces, and history: Art education and material culture studies. Arts and Learning Research, 10(1), 143-157.

Congdon, K. G. (1985). The study of folk art in our school's art classrooms: Some problems and considerations. Journal of Multi-cultural and Cross-cultural Research in Art Education, 3(1), 65-75.

Deetz, J. (1980, May/June). A sense of another world: History museums and cultural change. Museum News, 58 (2), 40-45.

Dissanayake, E. (1990). What is art for? Seattle, WA: University of Washington Press.

Fagg, W., \& Plass, M. (1964). African sculpture: An anthology. London, UK: Studio Vista Limited.

Fernandez, J. (1971). The mission of metaphor in expressive culture. Current Anthropology, 15(2), 119-145.

Gablik, S. (1995). Conversations before the end of time. NY: Thames \& Hudson.

Glassie, H. H. (1997). Art and life in Bangladesh. Bloomington, IN: Indiana University Press.

Gordon, R. B. (1993). The interpretation of artifacts in the history of technology. In S. Lubar, \& W. D. Kingery (Eds.), History from things: Essays on material culture (pp. 73-93). Washington, DC: Smithsonian Institution Press.

Gottdiener, M. (1995). Postmodern semiotics: Material culture and the forms of postmodern life. Oxford, UK: Blackwell.

Hooper-Greenhill, E. (1992). Museums and the shaping of knowledge. London, UK: Routledge.

Hudson, K. (1991). How misleading does an ethnographical museum have to be? In I. Karp, \& S. D. Lavine (Eds.), The Poetics and politics of museum display (pp. 457-464). Washington, DC. Smithsonian Institution Press. 
Janson, H. W., \& Janson, A. F. (1997). History of art. ( $5^{\text {th }}$ ed. Rev.). NY: Harry N. Abrams, Inc.

Kingery, W. D. (1993). Technological systems and some implications with regard to continuity and change. In S. Lubar, \& W. D. Kingery (Eds.), History from things: Essays on material culture (pp. 215-230). Washington, DC: Smithsonian Institution Press.

Lavine, I. (1983). The art of history: A professional allegory. ARTnews, 82(8), 96-101.

Lock, L. L. (Ed.). (1998). Winterthur portfolio: A journal of American material culture. Chicago, IL: The University of Chicago Press.

McFee, J. K., \& Degge, R. M. (1977). Art, culture, and the environment: A catalyst for teaching. Belmont, CA: Wadsworth Publishing Company Inc.

Newton, D. (1994). Old wine in new bottles, and the reverse. In F. E. S. Kaplan, (Ed.), Museums and the making of 'ourselves': The role of objects in national identity (pp. 269-290). London, UK: Leicester University Press.

Pearce, S. M. (1994). Museum studies in material culture. London, UK: Leicester University Press.

Pocius, G. L. (Ed.). (1991). Living in a material world: Canadian and American approaches to material culture. St. John's, Newfoundland, Canada: ISER.

Prown, J. D. (1991). On the 'art' in artifacts. In G. L. Pocius (Ed.), Living in a material world: Canadian and American approaches to material culture (pp. 144155). St. John's, Newfoundland, Canada: ISER.

Sesonske, A. (Ed.). (1965). What is art? Aesthetic theory from Plato to Tolstoy. New York: Oxford University Press Inc.

Silvers, A. (1999, Spring). Multiculturalism and the aesthetics of recognition: Reflections on celebrating pluralism. The Journal of Aesthetic Education, 33(1), 95-103.

Wallach, A. (1998). Exhibiting contradictions: Essays on the art museums in the United

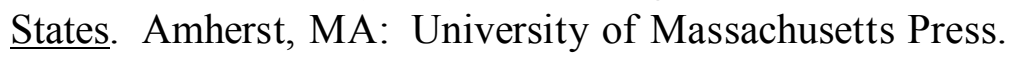

Weil, S. E. (1998 November/December). Courtly ghosts aristocratic artifacts: The art museum as palace. Museum News, 77(6), 44-49. 